\title{
The Research for Motivation, Characteristics and Effects of Direct Investment from Mainland to Hong Kong
}

\author{
En Chen \\ Jingwei Guangdong, Hong Kong and Macao Economic Research Center \\ Jinan University \\ Guangdong, China \\ E-mail: tchenen@163.com
}

\author{
Guaili Zhang \\ Nangfang College \\ Sun Yat-sen University \\ Guangdong, China \\ E-mail: $370098555 @$ qq.com
}

\author{
Tao Fu \\ Nangfang College \\ Sun Yat-sen University \\ Guangdong, China \\ E-mail: futaokaoyan@126.com
}

\begin{abstract}
Based on the analysis of background and motivation of the Mainland investing directly to Hong Kong, this essay, with some measurement methods, aims to explore the economic effects of these investments. The results showed that, in recent years, investment scale of the Mainland to Hong Kong has expanded rapidly. Hong Kong has become the largest destination of mainland investment and, the Mainland has become Hong Kong's largest source of foreign investment. On the one hand, maintaining a smooth transition and prosperity and stability of Hong Kong, enhancing the utilization of advantages of Hong Kong's service, improving the competitiveness of the manufacturing sector, acting as an intermediarv platform to expan d the international market. are the main motivations for Mainland enterprises investing in Hong Kong. On the other hand, investing in Hong Kong has contributed to economic growth in the Mainland, and promotion of economic and trade exchanges between the Mainland and Hong Kong. Focusing on some existing problems, the essay proposes on how to promote investments, including the optimization of the investment industry layout, promoting the expansion of investment in inland provinces and autonomous regions, encouraging private enterprises to expand investment in Hong Kong, and improving system of foreign investment promotion and service.
\end{abstract}

Keywords-Mainland and Hong Kong; Regional cooperation; external direct investment

\section{INTRODUCTION}

Foreign direct investment is an important way to a country or region participating in the international trade system. Since reform and opening, with the overall national strength continuing to improve, and the increase of level of

Fund Project: This is the 2013 annual Guangdong to build "theory of the PLA," funded project (project approval No: LLYJ1319) and the College of Humanities and Social Sciences in Guangdong Province major research project (project approval No: 10ZGXM79001) funded projects.. opening up, China's foreign direct investment in the mainland showing rapid development momentum. In2003, foreign direct investment flows to the mainland was $\$ 90.17$ billion, an increase of 671.9 times more than in 1984, an average annual increase of $24.2 \%$, faster than the global average of 12.3 percentage points; total flow of foreign direct investment worldwide scale accounted for $6.1 \%{ }^{1} 5.8$ percentage point increase over 1984. At present, foreign investment in Mainland China ranks first in developing countries and emerging economies, ranking third in the various countries and regions in the world, behind the United States and Japan.

The rapid expansion of foreign investment in the Mainland of China and its reinforcing global position, has arose a widespread concern in theory and practice, which become the focus of academic research in the field of home and abroad. At present, domestic and foreign scholars in this is sue focus on the aspects of foreign investment of Mianland in motivation, location, effects. In the study, Cai (1999), Liu yangchun (2008) and other scholars use the Eclectic theory, dominance theory to explore the motivation of Foreign Direct Investment, proposing that Chinese enterprises invest overseas due to internal factors including international competitive pressures, adapting to external factors of global development strategy, and expanding overseas markets, seeking strategic resources or learning advanced technology. In the aspects of area locations, Cheng Huifang (2004), Buckley et al (2007), Li Meng (2011) and other scholars, explore the location choices of foreign investment enterprises, from the host-economic characteristics of the

\footnotetext{
1 Data source: according to Handbook of Statistics On-line UNCTAD (2012) was calculated from the relevant data.Cai K.. Outward Foreign Direct Investment: A Novel Dimension of China's Integration into the Regional and Global Economy. China Quarterly [J].1999,160.
} 
angle, arguing that the distance of host country market size, resource endowment, trade links and other factors, have positive effects in attracting our direct investment. Kolstad \& Wiig (2009), Wang iian (2011) and other scholars from the host system level, examining the location choice of foreign investment enterprises and, thinking of the host country political stability, market economy restrictions institutional environment are also important factors in China's enterprises foreign investments. In the study of effect of existing literature main economic effects of foreign direct investment to China arising from trade, technology, employment, industry and other angles. Xiang benwu (2007), Liu ming xia (2010) other scholars found that, the development of China's foreign direct investment in the export trade, total factor productivity, economic growth and other aspects have generated significant promoting effect.

Acting as the bridge connecting the international market, Hong Kong is an important platform for Mainland enterprises "going out" and is the most important investment destination. By the end of 2013, non-financial direct investment in the Mainland, Hong Kong cumulative $\$ 361.95$ billion, the total share of the total non-financial overseas direct investment was $68.9 \%^{2}$. However, as the relevant data is difficult to collect, statistics are not complete and, other causes, current academic research on direct investment in mainland to Hong Kong is not so much and not deep enough. Therefore, this essay will base on data in the 1990s since, in-depth analysis of the background and motivation of the Mainland to Hong Kong investment, summary evolution and layout feature of Mainland to Hong Kong investment, and use measurement methods empirical analysis of economic effects of the Mainland to Hong Kong Investment on this basis, the proposed expansion of the Mainland to Hong Kong investment suggestions, developing strategies for China's foreign direct investment to provide a reference.

\section{THE BACKGROUND AND MOTIVAT ION OF MAINLAND TO HONG KONG DIRECT INVESTMENT}

\section{A. Mainland China continued to improve the comprehensive economic strength, after the United States became the world's second largest economy}

According to the eclectic theory of international production, the level of economic development of a country the size of its foreign direct investment is closely related with the improvement of the level of foreign net investment of economic development increases. Since the reform and opening up, China's economic and social develop ment of the mainland onto fast track to accelerate the expansion of the total economy, the comprehensive strength. In 1978, mainland GDP is only $\$ 214.16$ billion, ranked 15 in the world; only \$227.7 per capita GDP, equivalent to only $1 / 10$ of the world average, ranking No. 2 in the world countdown. In 2010, GDP growth in the Mainland to \$ 5.9 trillion, ranking second in the world after the United States, per capita GDP reached $\$ 4,514.9$, nearly half (48.8\%) of the

\footnotetext{
${ }^{2}$ Data source: Ministry of commerce website, www.mofcom.gov.cn.
}

global average, ranked No. 93 in the world. In 2013, mainland GDP of $\$ 9.2$ trillion, in 197842.9 times the average annual growth rate of 10.8 percent, more than the global average of 4.9 percent, is the world's fastest growing economy ${ }^{3}$.Per capita GDP reached \$29.6, 6747 times in 1978 , and the proportion of the global average of $64.3 \%, 53.8$ percentage points higher than in 1978. The continuous enhancement of economic strength, to provide a favorable economic conditions for the main land investment in Hong kong.

\section{B. The Mainland and Hong Kong have close geographical, cultural and historical ties}

From geographically contact point of view, in the southeastern tip of the Chinese mainland, Hong Kong, is located in the eastern side of the Pearl River estuary, northern Guangdong land connected with the mainland, water and land communication, from the capital of Guangdong province - Guangzhou, only $150 \mathrm{~km}$, with the mainland by rail, road, waterway, a variety of transportation and aviation mutual exchanges. Information from the popular point of view, there are a large number of mainland residents to move to Hong Kong, to participate in its inception and development of Hong Kong, which migrate to the residents of Hong Kong and the mainland compatriots the long maintained close relationship and civil exchanges. At present, the composition of the population of Hong Kong, the Chinese account for $94 \%$, with a population about onethird boring in the Mainland. From the cultural ties, the Mainland and Hong Kong belong to the Guangdong Lingnan culture system, context is connected to the same language, customs similar. Currently, about 90 percent of Hong Kong Cantonese as usual language. Thus, the Mainland and Hong Kong have geopolitical close, blood pro, text edge deep natural advantages, provided favorable conditions for mainland enterprises to carry out the history of direct investment in Hong Kong.

\section{Mainland and Hong Kong economic had trade partnership integration}

Early in the Ming and Oing period, Hong Kong is China's important foreign trade port, is an important bridge for the mainland's foreign trade at the time. Since the reform and opening up the mainland, effectively undertake industrial transfer of Hong Kong, to form a "front shop" model of cooperation with Hong Kong, to promote the formation of two interdependent, complementary and mutually beneficial economic and trade cooperation pattern of solidarity. From the point of view of the mainland, in 2013, the Mainland and Hong Kong import and export amounted to 401.01 billion US dollars, total imports and exports accounted for the proportion of the mainland was $9.6 \%$. At present, Hong Kong has become the mainland's fourth largest trading partner and third largest export market and the largest reexport platform. From the perspective of Hong Kong, in 2013, the amount of import and e xport trade between Hong Kong and the Mainland to HK \$ 3.89138 trillion, accounting

\footnotetext{
${ }^{3}$ Dat a source: National Bureau of Statistics website, www.st at s.gov.cn.
} 
for $51.1 \%$ of the total import and export trade of Hong Kong. Among them, the Mainland and re-exports amounted to HK \$ 1.92446 trillion, accounting for $54.9 \%$ of Hong Kong's total re-exports. Currently, the mainland has become Hong Kong's largest trading partner, trade volume ranked first in Hong Kong export destination and import source location. Close economic and trade relations, the Mainland to Hong Kong investment has laid a solid economic foundation.

\section{D. serve the Hong Kong community, social and political stability of our economy motivation}

Political factors are special motive the eighties and nineties the Mainland to Hong Kong investment. Hong Kong's sovereignty to a transitional period, before and after, by the Chinese and British sides appear Constitutional arguments, the impact of international anti-China forces "trouble" and other factors, some Hong Kong people lack confidence in the future economic and social development of Hong Kong, once a "migration ." To ensure a smooth transition and smooth return of Hong Kong, the Central Government with the power of Hong Kong-funded enterprises, through the acquisition of Hong Kong's local bankrupt enterprises to participate in Hong Kong's major infrastructure construction, etc., to increase direct investment in Hong Kong to enhance Hong Kong people on the Hong Kong economy confidence and social development. For example, the 1984 BOC Hong Kong, China Resources Group, China Merchants to HK \$ 470 million acquisition of a joint venture in Hong Kong facing closure largest electronics company Conic Investment, tens of thousands of employees from unemployment; China International Trust and Investment Corporation in 1985 to HK \$ 350 million to acquire the brink bankruptcy Ka Wah Bank, then again in 1990 to HK \$ 10 billion takeover of Hong Kong Telecom Company Limited 20\%; and in 1986 acquired the bankrupt listed China Merchants Bank - Union Bank (Union Bank).

\section{E. Advantages of using Hong Kong as an international financial, trade and shipping center, serving mainland manufacturing sector}

In1980s and 1990s, Hong Kong successfully achieved the industry transformation, the establishment of a finance, trade, logistics as the main service-based economy, and gradually became known as an international financial, trade and shipping center. 1981-2012, the Hong Kong service industry rapidly increased from $\mathrm{HK} \$ 111.2$ billion to HK $\$ 1.8725$ trillion, the service sector share of GDP increased from $67.5 \%$ to $91.9 \%$, services exports increased from HK $\$ 21.8$ billion to HK $\$ 764$ billion. In this context, mainland enterprises to invest in Hong Kong is an important motive is that the use of Hong Kong's highly developed service industry system, promote the advantages of Hong Kong's service with its own manufacturing advantages of organic combination, to enhance the international competitiveness of the manufacturing sector. Specific Approaches include: first, to carry out capital operation activity on Hong Kong's financial markets, access to and the quality of the factors of production overseas, Hong Kong, and further enhance production and management advantages in the international market. For example, the August 2003 acquisition of Hong Kong listed company BOE - TPV Technology $26.36 \%$ stake, in order to obtain the photoelectric technology. Second, to carry out the investment in Hong Kong, relying on Hong Kong's commerce system developed to establish overseas business network, to achieve effective integration of domestic and foreign marketing market. For example, the 1996 TCL Group acquired the company in Hong Kong Luks TV project, to build a platform to take advantage of Hong Kong's overseas business networks. Second, to carry out the investment, and establish overseas marketing and supporting the transportation, warehousing and other intermediary service system in Hong Kong, in order to reduce transaction costs and promote trade activities. For example, China Resources Group, China Merchants and other companies have invested in Hong Kong Container Terminal, air transport, warehousing and other trade-related intermediary services industry.

\section{F. Use of Hong Kong "free port" and the advantages of lower tax rates in order to Hong Kong as an intermediary in international operations}

The general rules of international foreign investment are consistent motivation to carry out international operations, expanding overseas market is one important motivation for mainland enterprises to invest in Hong Kong. Hong Kong's international economic system, high degree of market, mainland enterprises to overseas optimal operating platform. In the economic system, the HKSAR government has long implementation of "positive non-intervention" policy, the establishment of a high degree of liberalization of economic management system, fewer restrictions on foreign investment. According to the American Heritage Foundation in January 2013 announcing the "Index of Economic Freedom" report, Hong Kong 19 consecutive years was named the world's freest economies. In the business environment, the Hong Kong SAR government clean and efficient, transparent legal system, tax system is simple, lower tax, improve infrastructure, facilitating the flow of information, thus have a good investment environment. The associated location, Hong Kong as the world's investment center, in close contact with the international market, market rules, mode of operation with the world, mainland enterprises, "a borrowed boat," the ideal place. As Hong Kong has a unique advantage over mainland enterprises, as a platform for the implementation of "going out" strategy. Ministry of Commerce statistics showed that foreign direct investment in the mainland by 65 percent in Hong Kong to invest in the world ${ }^{4}$.

\section{LAYOUT FEATURES OF DIRECT INVESTMENT INTHE MAINLAND TO HONG KONG}

Because of the close geographical, cultural and economic ties, investment in the mainland to Hong Kong has a long history. As early as the late Qing Dynasty and early Republic of China, a number of government-run institutions began to

\footnotetext{
${ }^{4}$ Source: mainland foreign direct investment six into the Hongkong as a springboard to the South [N]. 2012-08-23.
} 
set up branches in Hong Kong, when the Merchants, Commercial Press and other Chinese enterprises have set up in Hong Kong. Since the founding of new China in 1949, the Mainland to Hong Kong investment developed rapidly, its historical evolution can be divided into four stages: the first stage is trade services investment phase (1949-1978). During this period, the mainland is main ly established in Hong Kong trading enterprises, expand foreign economic and trade exchanges, the import of some essential means of production, means of subsistence and strategic materials, in order to break the economic blockade of western countries. The second stage is to expand the open investment phase (19791996). During this period, the implementation of reforms and opening-up strategy, set up in Hong Kong, a number of "windows" business, to introduce overseas capital factors of production, technology, equipment, strategic resources, and close economic ties with overseas, to support mainland's economic development. The third stage is the policy of stable investment phase (1997-2003). During this period, Hong Kong has suffered from the impact of the Asian financial crisis, SARS and other economic downturn was falling, the phenomenon appears to evacuate international capital. To this end, the mainland to invest in the field of the Hong Kong people's livelihood, infrastructure, the withdrawal of fore ign investment to fill the vacancy, in order to maintain the prosperity and stability of Hong Kong's economy and society. The fourth stage is the intermediary platform-based investment phase (2004-present). During this period, as the CEPA and its supplementary agreement to gradually reduce the Mainland and Hong Kong institutional barriers in trade between the mainland and further increase investment in Hong Kong, relying on the institutional strengths of Hong Kong as an international financial, trade center and free port status, Hong Kong as a "springboard" to actively explore the international market. Generally speaking, the current investment in the mainland in Hong Kong showed the following layout features:

\section{A. Hong Kong is the mainland's largest destination for foreign investment}

In recent years, especially since the implementation of CEPA, the scale of investment in the Mainland to Hong Kong's rapidly expanding Hong Kong's long-term status of the mainland's largest foreign investment destination. From the traffic point of view, according to Commerce Department statistics, the National Statistics Bureau and other departments, the flow during the year 2012 to direct investment in Hong Kong was \$ 51.24 billion, an increase of 43.6 times compared with 2003, total foreign investment flow in the Mainland accounted for $58.4 \%$ increase 18.2 percentage points higher than in 2003, compared with the second highest British Virgin Islands high 39.5 points. From the stock point of view, the end of 2012 the stock of direct investment in the main land to Hong Kong to $\$ 306.37$ billion, an increase of 11.4 times co mpared with the end of 2003, the proportion of total foreign investment flows to the mainland was 57.6\% higher than the second highest of the British Virgin Is lands 51.8 percentage points.

TABLE I. $2003-2012$ CHANGE THE SITUATION IN HONG KONG DIRECT INVESTMENT

\begin{tabular}{|c|c|c|c|c|}
\hline Year & Flow & Percentage & Retain & Pnits : billion US do llars, $\%$ \\
\hline $\mathbf{2 0 0 3}$ & 11.5 & 40.2 & 246.3 & 74.1 \\
\hline $\mathbf{2 0 0 4}$ & 26.3 & 47.8 & 303.9 & 67.9 \\
\hline $\mathbf{2 0 0 5}$ & 34.2 & 27.9 & 365.1 & 63.8 \\
\hline $\mathbf{2 0 0 6}$ & 69.3 & 39.3 & 422.7 & 56.3 \\
\hline $\mathbf{2 0 0 7}$ & 137.3 & 51.8 & 687.8 & 58.3 \\
\hline $\mathbf{2 0 0 8}$ & 386.4 & 69.1 & 1158.5 & 63.0 \\
\hline $\mathbf{2 0 0 9}$ & 356.0 & 63.0 & 1645.0 & 66.9 \\
\hline $\mathbf{2 0 1 0}$ & 385.1 & 56.0 & 1990.6 & 62.8 \\
\hline $\mathbf{2 0 1 1}$ & 356.6 & 47.8 & 2615.2 & 61.6 \\
\hline $\mathbf{2 0 1 2}$ & 512.4 & 58.4 & 3063.7 & 57.6 \\
\hline
\end{tabular}

a. Source: Ministry of Commerce, National Bureau of Statistics, the State Administration of Foreig Exchange, "Statistical Bulletin of China's foreign direct investment" (each year)

TABLE II. FOREIGN DIRECT INVESTMENT IN THE MAINLAND OF THE TOP FIVE COUNTRIES AND REGIONS

\begin{tabular}{|c|c|c|c|c|c|c|}
\hline \multirow{2}{*}{ No } & \multicolumn{3}{|c|}{2012 annual flow } & \multicolumn{2}{c|}{ 2012 year-end stocks } \\
\cline { 2 - 7 } & Country (Region) & Scale & Percentage & Country (Region) & Scale & Percentage \\
\hline 1 & Hong Kong & 512.4 & 58.4 & Hong Kong & 3063.7 & 57.6 \\
\hline 2 & United States & 40.5 & 4.6 & British Virgin Islands & 308.5 & 5.8 \\
\hline 3 & Kazakhstan & 29.9 & 3.4 & Cayman Islands & 300.7 & 5.7 \\
\hline 4 & England & 27.8 & 3.2 & United States & 170.8 & 3.2 \\
\hline 5 & British Virgin Islands & 22.4 & 2.6 & Australia & 138.7 & 2.6 \\
\hline & Others & 245 & 27.8 & Others & 1337 & 25.1 \\
\hline Total & & 878 & 100 & & 5319.4 & 100 \\
\hline
\end{tabular}

Units : billion US dollars, $\%$

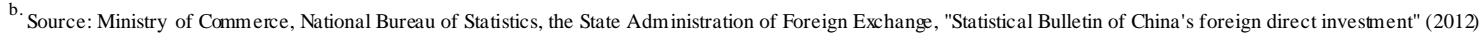

B. Mainland Beyond Britain, the United States, Germany and other countries to become Hong Kong's largest source offoreign investment

From the traffic point of view, according to the Hong Kong SAR Census and Statistics Department statistics, during the year 2012 to Hong Kong direct investment to flow to the United States to HK \$ 232.7 billion, an increase of 10.5 times compared with 1998, the proportion of Hong
Kong's total foreign investment flow was $42.8 \%$, compared with 1998 increase 25.1 percent. From the stock point of view, the end of 2012 the stock of direct investment in the mainland to Hong Kong to HK \$ 3.5683 trillion, an increase of 15.7 times compared with the end of 1998, the proportion of Hong Kong's total foreign investment stock was 37.0 percent, up 24.7 percentage points from the end of 1998. At present, investment in the mainland to Hong Kong is not only more than the British, American, Dutch and other 
countries, and more than the world's tax havens - British Virgin Islands, to become Hong Kong's largest source of

foreign investment.

TABLE III. 1998--2012 ForEIGN DIRECT INVESTMENTPOSITION IN FOREIGN DIRECT INVESTMENT IN HONG KONG

Units: million, \%

\begin{tabular}{|c|c|c|c|c|}
\hline Yean & $\begin{array}{l}\text { Mainland to Hong Kong } \\
\text { in vestment flows }\end{array}$ & $\begin{array}{l}\text { in vestment flows of foreign capital accounted for } \\
\text { the proportion of mainland }\end{array}$ & $\begin{array}{c}\text { Mainland in vestment stock in } \\
\text { Hong Kong }\end{array}$ & $\begin{array}{l}\text { The proportion of foreign capital } \\
\text { in Hong Kong }\end{array}$ \\
\hline 1998 & 202 & 17.7 & 2137 & 12.3 \\
\hline 1999 & 386 & 20.2 & 8148 & 25.9 \\
\hline 2000 & 1107 & 23.0 & 11122 & 31.3 \\
\hline 2001 & 385 & 20.8 & 9581 & 29.3 \\
\hline 2002 & 317 & 42.0 & 5946 & 22.7 \\
\hline 2003 & 380 & 35.7 & 7701 & 26.0 \\
\hline 2004 & 620 & 23.4 & 10201 & 29.0 \\
\hline 2005 & 729 & 27.9 & 12719 & 31.4 \\
\hline 2006 & 1087 & 31.1 & 20243 & 35.1 \\
\hline 2007 & 1042 & 24.6 & 37374 & 40.7 \\
\hline 2008 & 1797 & 38.7 & 23114 & 36.5 \\
\hline 2009 & 2148 & 49.9 & 26036 & 37.1 \\
\hline 2010 & 2882 & 52.6 & 31271 & 37.7 \\
\hline 2011 & 3181 & 42.3 & 30428 & 36.3 \\
\hline 2012 & 2327 & 42.8 & 35683 & 37.0 \\
\hline
\end{tabular}

${ }^{c}$ Source: Hong Kong SAR Census and Statistics Department, "Foreign Direct Investment Statistics of Hong Kong" (each y ear)

\section{Central and local state-owned enterprises is an important subject in the Mainland to Hong Kong investment}

Since reform and opening to the late 20th century, the Mainland to Hong Kong to expand foreign trade and economic ties as the main bridge and window, central ministries as well as provincial, city and county governments have to invest in Hong Kong, set up a "window" business in Hong Kong.Central ministries and commissions set up in Hong Kong, "window" overseas group companies, including China Huadian Corporation, China Statistical consulting companies, provincial and municipal government set up a "window" Group companies, including Guangdong, Huamin Group, Beijing Holdings, China Sea Group . Currently, the central min istries set up in Hong Kong, "window" more than 60 enterprises, local governments set up in Hong Kong, "window" enterprises have more than 40. These state-owned enterprises have become the main force in the Mainland to invest in Hong Kong, occupies an important position in the Hong Kong economy. For example, in the financial sector, Bank of China is also a major supplier of the clearing bank for RMB business in Hong Kong, the main market makers RMB exchange market, the RMB cash market, Hong Kong has become one of the market's strongest banks. Supplies in areas of life, Hong Kong's vegetables, meat and poultry, fresh water, natural gas and other basic supplies mainly rely on long-term supply mainland, the vast majority of business is borne by the state-owned enterprise established in Hong Kong. At present, the Dongjiang accounted for more than $75 \%$ of total water supply in Hong Kong, mainland supply of live pigs, cattle, chickens more than $70 \%$ of total supply in Hong Kong, Chinese enterprises of various types of distribution of refined oil accounted for $25 \%$ of total sales in Hong Kong market ${ }^{5}$.

D. Service sector, especially business services, financial industry to become the leading industry in the Mainland investment in Hong Kong

Obey three industrial point of view, the end of 2012, the cumulative total investment in the mainland to Hong Kong, the tertiary industry accounted for more than $87.6 \%$, respectively, higher than the first and secondary industries accounted for $87.5,75.3$ percentage points.

From the point of view of internal services, at the end of 2012, business services, finance, wholesale and retail, transportation and other industries in the proportion of the cumulative amount of investment in the mainland to Hong Kong were $39 \%, 20.3 \%, 16 \%, 7.2 \%$, of the four and more than $80 \%$, is the most concentrated areas of mainland investment in Hong Kong, show most dynamic companies investing in the mainland, Hong Kong because Hong Kong is to take advantage of trade, finance, international shipping center to expand overseas markets. Mining industry in Hong Kong is the mainland accounted for a larger investment, rising faster in the industry. The end of 2012, accounting for the mining industry in the Mainland investment in Hong Kong was 8.6 percent, up 6.7 percentage points compared with the end of 2008, indicating that more and more emphasis on the use of Mainland enterprises in Hong Kong as a platform to acquire overseas strategic resource.

\footnotetext{
${ }^{5}$ Source: Hongkong Chinese funded enterprises to make an important contribution to the prosperity and stability of Hongkong [EB/OL]., www.xinhuanet.com, 2007-06-28.
} 
TABLE IV. 2008 - THE END OF2012 THE INDUSTRY DistribUtION OF THE MAINLAND TO HONG KONG'S DiRECT INVESTMENT STOCK

\begin{tabular}{|l|c|c|c|c|c|}
\hline Industry & $\mathbf{2 0 0 8}$ & $\mathbf{2 0 0 9}$ & $\mathbf{2 0 1 0}$ & $\mathbf{2 0 1 1}$ & $\mathbf{2 0 1 2}$ \\
\hline primary industry & - & - & - & 0.1 & 0.1 \\
\hline Agriculture, forestry, animal husbandry, fishery & - & - & - & 0.1 & 0.1 \\
\hline Secondary industry & 5.4 & 16.7 & 13.2 & 15.5 & 12.3 \\
\hline Manufact uring & 3.1 & 3.1 & 2.6 & 4.1 & 3.3 \\
\hline mining industry & 1.9 & 13.3 & 10.3 & 11.1 & 8.6 \\
\hline Building industry & 0.4 & 0.3 & 0.3 & 0.3 & 0.4 \\
\hline Tertiary Industry & 94.6 & 83.3 & 86.8 & 84.4 & 87.6 \\
\hline Business Services & 30.2 & 28.2 & 30.8 & 35.7 & 39 \\
\hline Financial Industry & 26.9 & 24.2 & 22.7 & 20.4 & 20.3 \\
\hline Wholesale and retail trade & 22.5 & 18.6 & 17.9 & 15.6 & 16 \\
\hline Transportation, storage and postal services & 9.8 & 7.9 & 9.4 & 7.6 & 7.2 \\
\hline Real Estate & 2.9 & 2.4 & 3 & 2.8 & 2.4 \\
\hline Water Conservancy, Environment and Public Facilities Management & 0.9 & 0.7 & 0.6 & 0.9 & - \\
\hline Electricity, gas and water production and supply industry & 0.3 & 0.2 & 0.2 & 0.4 & 0.4 \\
\hline Resident Services and Other Services & 0.4 & 0.4 & 1.3 & 0.3 & 0.8 \\
\hline Information transmission, computer and soft ware industry & - & 0.3 & 0.4 & 0.3 & 1 \\
\hline Scientific Research, Technical Services and Geological Prospect ing & - & 0.3 & 0.2 & 0.2 & 0.3 \\
\hline Culture, Sports and Entertainment & - & - & 0.1 & 0.1 & 0.1 \\
\hline Accommodation and Catering Services & - & - & 0.1 & 0.1 & 0.1 \\
\hline Others & 0.7 & 0.1 & 0.1 & - & - \\
\hline Total & 100 & 100 & 100 & 100 & 100 \\
\hline
\end{tabular}

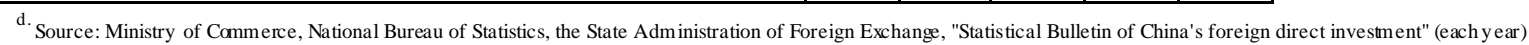

\section{E. Intermediary and a platform in foreign investment in the} mainland, Hong Kong has become increasingly prominent

As more and more mainland enterprises to Hong Kong as a "going out" and "training grounds", the role of intermed iary and platform foreign investment in Hong Kong in the mainland have become increasingly prominent. According to the survey the Hong Kong SAR Census and Statistics Department data released by the end of 2013 , according to the division responsible for managing the area outside the corporate regional headquarters in Hong Kong, responsible for the management and operation of enterprises in the Mainland have regional headquarters in Hong Kong 1128 , the total area of overseas companies in Hong Kong headquarters proportion was $81.8 \%$, of which the region is responsible for managing business affairs of the headquarters of Guangdong accounted for $26.5 \%$. According to the division responsible for managing the area of foreign enterprises in regional offices in Hong Kong, responsible for the management and operation of enterprises in the Mainland regional offices in Hong Kong 1912, accounting for all the regional offices of foreign enterprises in Hong Kong accounted for $77.9 \%$, which is responsible for managing Guangdong business affairs regional offices accounted for $28.1 \%$.

TABLE V. 2005 - THE END OF2013. MAINLAND BUSINESSENTERPRISES RESPONSIBLE FOR MANAGING REgIONAL HEADQUARTERS, REGIONAL OFHCES

\begin{tabular}{|c|c|c|c|c|c|c|c|c|c|c|c|c|}
\hline \multirow{2}{*}{ Year } & \multicolumn{6}{|c|}{ Regional Headquarters } & \multicolumn{6}{|c|}{ Regional Offices } \\
\hline & Inland & Percentage & Guangdong & Percentage & Others & Percentage & Inland & Percentage & Guangdong & Percentage & Others & Percentage \\
\hline 2005 & 1046 & 89.6 & 324 & 27.8 & 185 & 15.9 & 2212 & 84.1 & 784 & 29.8 & 355 & 13.5 \\
\hline 2006 & 1073 & 87.4 & 294 & 23.9 & 193 & 15.7 & 2182 & 83.4 & 780 & 29.8 & 326 & 12.5 \\
\hline 2007 & 1089 & 87.4 & 308 & 24.7 & 152 & 12.2 & 2176 & 82.3 & 728 & 27.5 & 292 & 11 \\
\hline 2008 & 1138 & 87.7 & 365 & 28.1 & 178 & 13.7 & 2133 & 82.5 & 800 & 31 & 308 & 11.9 \\
\hline 2009 & 1079 & 86.2 & 355 & 28.4 & 247 & 19.7 & 1898 & 81.5 & 720 & 30.9 & 428 & 18.4 \\
\hline 2010 & 1102 & 85.8 & 362 & 28.2 & 274 & 21.3 & 1881 & 79.9 & 711 & 30.2 & 461 & 19.6 \\
\hline 2011 & 1120 & 83.6 & 356 & 26.6 & 288 & 21.5 & 1911 & 79.2 & 693 & 28.7 & 494 & 20.5 \\
\hline 2012 & 1137 & 83.2 & 357 & 26.1 & 301 & 22 & 1989 & 79.1 & 707 & 28.1 & 502 & 20 \\
\hline 2013 & 1128 & 81.8 & 365 & 26.5 & 297 & 21.5 & 1912 & 77.9 & 691 & 28.1 & 449 & 18.3 \\
\hline
\end{tabular}

e. Note: A regional headquarters is outside Hong Kong parent company on behalf of the region (ie Hong Kong plus one or more other places) office has the right to manage an agency; Regional Office is responsible for the coordination area refers to the parent company on behalf of Hong Kong overseas (ie Hong Kong plus one or more other places) and the offices of an organization or operations.

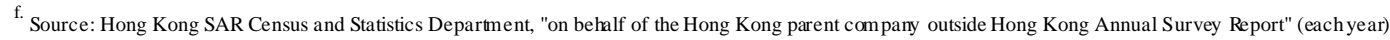




\section{F. Guangdong is the most active investment in the} mainland to Hong Kong, the largest cross-border capital flows provinces

Guangdong and Hong Kong have close since the geopolitical, popularity links and close economic and trade exchanges, and in the forefront of reform and opening up the mainland, the main land has always been the most active on the Hong Kong investment, cross-border capital flows largest provinces. From the fore ign investment scale, the end of 2012, Guangdong's foreign direct investment stock of \$ 25.18 billion, is the largest foreign investment in the mainland province, ranking second in Shanghai more than $80.5 \%$; total stock of foreign direct investment in the Mainland accounted for $5.8 \%, 2.6$ percentage points higher than in Shanghai. Foreign investment in Guangdong, Hong Kong is the main destination. In 2011, Guangdong to Hong Kong investment in the amount of $\$ 2.19$ billion, accounting for the total foreign investment accounted for 75.5 percent. From the point of view of cross-border capital flows, in 2012, Guangdong accounted for the total cross-border capital outflows scale cross-border capital outflow mainland accounted for 17.6 percent, is the mainland cross-border capital flows the most active provinces. The outflow of funds in Guangdong cross-border scale, the flow of the highest proportion of Hong Kong. In2012, Guangdong to Hong Kong cross-border capital outflows in the proportion of the province's total cross-border capital outflow was $50.8 \%$.

TABLE VI. THE END OF 2012 THE STOCK OF FOREIGN INVESTMENT IN THE MAINLAND AREAS OF THE TOP FIVE

Units: billion US dollars; \%

\begin{tabular}{|c|l|l|l|}
\hline No & \multicolumn{1}{|c|}{ Region } & \multicolumn{1}{|c|}{ Stocks } & Percentage \\
\hline 1 & Guangdong & 251.8 & 5.8 \\
\hline 2 & Shanghai & 139.5 & 3.2 \\
\hline 3 & Shandong & 119.7 & 2.7 \\
\hline 4 & Zhejiang & 85.5 & 2.0 \\
\hline 5 & Beijing & 75.8 & 1.7 \\
\hline
\end{tabular}

${ }^{\text {g. }}$ Source: Ministry of Commerce, National Bureau of Statistics, the State Administration of Foreign Exchange, "Statistical Bulletin of China's foreign direct invesment" (2011).

\section{EFFECT AND THE MAINLANDTO HONG KONG DIRECT INVESTMENT}

From a theoretical point of view, the rapid growth of the mainland to Hong Kong direct investment, have the following economic effects: on the one hand, by promoting industrial upgrading, get the reverse technology spillover, expanding employment, access to strategic assets and other means to promote economic growth in the Mainland; the other on the one hand, driven by capital, goods, people and the free flow of production factors such as optimal allocation between the Mainland and Hong Kong, to promote economic and trade cooperation between the Mainland and Hong Kong. However, due to lack of proper planning and guidance, the Mainland to Hong Kong to invest in the industry, layout, regional distribution, investment and other aspects of the subject, there are some problems, growth potential will be restricted. From the empirical point of view and experience, further analysis of the following effects and the Mainland to Hong Kong direct investment.

\section{A. An Empirical Analysis of the Mainland investment} promotion effect on economic growth in the Mainland in Hong Kong

Mainland gross production (GDP), investment (ODI) in the Mainland to Hong Kong two variables, structure equation cointegration and error correction model to analyze the effect of investment in the Mainland to promote Hong Kong's economic growth in the Mainland. Gross inland product (GDP) data from the International Monetary Fund (IMF) WEO database, in dollars at current prices for the units; data Mainland to Hong Kong investment (ODI) from the Hong Kong SAR Census and Statistics Department ${ }^{6}$.The sequence length is 1990-2012 years (1990-1997 data is estimated from the existing Hongkong foreign investment data), and the exchange rate is converted into US dollars at the end of the year. In order to eliminate the differences, the natural logarithm of the variables, respectively, were recorded as $\ln$ GDP and lnODI.

ADF test results show that the two variables of $\ln$ ODI and $\ln$ GDP are non-stationary, and their first order difference is stable, and the precondition of co integration test is satisfied.

TABLE VII. ADF STATIONARY TEST RESULTS AND LNODI OF LNGDP

\begin{tabular}{|c|l|l|l|l|}
\hline Variable & $\begin{array}{c}\text { Inspection } \\
\text { Type }(\mathbf{c}, \mathbf{t}, \mathbf{k})\end{array}$ & $\begin{array}{c}\text { ADF } \\
\text { Inspection }\end{array}$ & $\begin{array}{c}\mathbf{5 \%} \\
\text { Threshold }\end{array}$ & Smooth \\
\hline $\ln$ GDP & $(\mathrm{c}, 0,4)$ & 1.2199 & -3.0048 & Not smooth \\
\hline$\triangle \ln \mathrm{GDP}$ & $(\mathrm{c}, 0,4)$ & -5.1146 & -3.0123 & Smooth \\
\hline $\ln \mathrm{ODI}$ & $(\mathrm{c}, 0,4)$ & -0.6180 & -3.0048 & Not smooth \\
\hline$\Delta \ln \mathrm{ODI}$ & $(\mathrm{c}, 0,0)$ & -4.9268 & -3.0123 & Smooth \\
\hline
\end{tabular}

The method of using Johansen Cointegration test lnGDP and $\ln$ ODI between two variables. Cointegration test results show, at the 5\% significance level, between two variables $\ln$ ODI $\ln$ GDP and only one cointegration relationship.

TABLE VIII. JOHANSEN COINTEGRATION TEST RESULTS AND INODE OF LNGDP

\begin{tabular}{|c|l|l|l|}
\hline Null hypothesis & Eigen values & Trace statistics & $\begin{array}{c}\mathbf{5 \%} \\
\text { Threshold }\end{array}$ \\
\hline 0 coint egration vector & 0.5904 & 23.6139 & 0.0166 \\
\hline $\begin{array}{c}\text { At most 1 } \\
\text { coint egrat ion vectors }\end{array}$ & 0.2502 & 5.7602 & 0.2101 \\
\hline
\end{tabular}

Measurement results show that the long-term equilibrium equation $\ln$ GDP and $\ln$ ODI two variables are:

$\ln G D P=0.5944 * \ln O D I+2.8898$

$$
\text { T value (15.77) (42.96) }
$$

Cointegration equation shows that in the long run, economic growth in the Mainland, Hong Kong and the Mainland investment between the existence of a long-term stable relationship. Among them, the economic growth in the Mainland for elastic Mainland investment in Hong Kong is

\footnotetext{
${ }^{6}$ Compared with the statistics of the mainland, the Hongkong SAR Government on the mainland of Hongkong direct investment in the statistics of a longer time, more suitable for quant it ative analysis.
} 
0.5944. In other words, investment in the mainland in Hong Kong every $1 \%$ increase, will boost economic growth in the Mainland $0.5944 \%$.

Further establish $\operatorname{lnGDP}$ and inODE error correction model. Measurement results below formula:

$$
\begin{array}{lll}
\Delta \ln G D P_{t}=0.1621^{*} \Delta \ln O D I_{t}+0.1265 * \Delta \ln O D I_{t-1}-0.0537 * \Delta e c m_{t-1} \\
\text { T value }
\end{array}
$$

Correction term correction coefficient $(-0.0537)$ is less than zero, in line with the principle of reverse correction mechanism. Model estimation results indicate that the dynamic relationship between the short term, growth in the mainland economy (ln GDP) of short-term fluctuations in the mainland by Hong Kong investment (lnODI) short-term changes. When short-term fluctuations deviate from longterm equilibriu m, non-equilibriu m error ratio will be 0.0537 on economic growth in the Mainland to make a correction. This suggests that investment in the mainland in Hong Kong on economic growth in the Mainland to form a positive feedback mechanism, and promoting economic growth in the Mainland.

\section{B. Mainland investment in economic and trade cooperation between the Mainland and Hong Kong in Hong Kong promoting effect of empirical analysis}

Using co integration equation and error correction model, the promotion effect of mainland investment in Hongkong (ODI) on economic and trade cooperation between China and Hongkong is analyzed. In the process of empirical analysis, selecting trade with the index, 16 (Itra as a measure of economic and trade cooperation between Mainland and Hong Kong tightness index, the index data sources to the United Nations UNCTADstat database, the time length for 2012. In order to eliminate the difference, the natural logarithm of the number of variables, denoted as $\ln I$.

ADF test results show that, with the same $\ln$ ODI, $\ln I$ is not stable at the 5\% significant level, and its first order difference is stable, and it satisfies the precondition of co integration test.

Using co integration equation and error correction model, the promotion effect of mainland investment in Hongkong (ODI) on economic and trade cooperation between China and Hongkong is analyzed. In the process of empirical analysis, selecting trade with the index , (Itra) as a measure of economic and trade cooperation between Mainland and Hong Kong tightness index, the index data sources to the United Nations UNCTADstat database, the time length for 2012. In order to eliminate the difference, the natural logarithm of the number of variables, denoted as $\ln I$.

ADF test results show that, with the same $\ln$ ODI, $\ln I$ is not stable at the 5\% significant level, and its first order

\footnotetext{
${ }^{7}$ Trade union index was first proposed by economist Brown (A.J.Brown) in 1947 , mainly used to reflect the degree of interdependence between the two countries trade. Calculation formula for $\mathrm{Iab}=(\mathrm{Xab} / \mathrm{Xa}) /(\mathrm{Mb} / \mathrm{Mw}), \mathrm{Xab}$ for the a country exports to B, Xa for a country exports, Mb for the B country imports, Mw for the world's total imports. The ratio is 1 for the average, the great er the value, the more closely the two countries in terms of trade.
}

difference is stable, and it satisfies the precondition of co integration test.

TABLE IX. LNI ANDLNODI ADFTABLETEST RESULTS

\begin{tabular}{|c|c|c|c|c|}
\hline Variable & $\begin{array}{c}\text { test type }(\mathbf{c}, \mathbf{t}, \\
\mathbf{k})\end{array}$ & $\begin{array}{c}\text { ADF } \\
\text { test }\end{array}$ & $\begin{array}{c}\mathbf{5 \%} \\
\text { critical }\end{array}$ & $\begin{array}{c}\text { value of } \\
\text { stability }\end{array}$ \\
\hline $\ln \mathrm{I}$ & $(\mathrm{c}, 1,4)$ & 1.0382 & -1.9581 & Not stable \\
\hline$\Delta \ln \mathrm{I}$ & $(\mathrm{c}, 0,0)$ & -6.6379 & -3.0123 & smooth \\
\hline $\ln \mathrm{ODI}$ & $(\mathrm{c}, 0,4)$ & -0.6180 & -3.0048 & Not stable \\
\hline$\Delta \ln \mathrm{ODI}$ & $(\mathrm{c}, 0,0)$ & -4.9268 & -3.0123 & smooth \\
\hline
\end{tabular}

Using Johansen method to test the co integration relationship between the two variables of $\ln$ ODI and $\ln I$. Cointegration test results show that, at the level of $5 \%$, there is only one co integration relationship between $\ln$ I and $\ln \mathrm{ODI}$ two variables.

TABLE $X$. JOHANSEN COINTEGRATION TEST RESULTS FOR LNODI AND LNI

\begin{tabular}{|c|c|c|c|}
\hline Null hypothesis & Eigen values & $\begin{array}{c}\text { Trace } \\
\text { statistics }\end{array}$ & $\begin{array}{c}\mathbf{5 \%} \\
\text { Th reshol d }\end{array}$ \\
\hline 0 coint egration vector & 0.5200 & 21.6180 & 0.0323 \\
\hline $\begin{array}{c}\text { At most 1 coint egration } \\
\text { vectors }\end{array}$ & 0.2557 & 6.2025 & 0.1756 \\
\hline
\end{tabular}

The measurement results show that the long-run equilibriu m equation between $\ln I$ and $\ln \mathrm{ODI}$ is:

$$
\ln I=0.0862 * \ln O D I+1.6109
$$

$$
\text { T value }
$$

From the co integration equation, we can know that there is a long-term stable relationship between the mainland and Hongkong in the long term, the trade between the mainland and Hongkong. Among them, the degree of trade between the main land and Hongkong for the mainland investment in Hongkong's elasticity is 0.0862 . That is to say, the mainland investment in Hongkong every $1 \%$, will boost the trade between the main land and Hongkong increased by $0.0862 \%$.

The error correction model of $\operatorname{lnI}$ and $\operatorname{lnODI}$ is further established. The measurement results are shown in the following formula:

$$
\begin{aligned}
& \Delta \ln I_{t}=0.0897 * \Delta \ln O D I_{t}-0.6727 * \Delta e c m_{t-1} \\
& \text { T value }
\end{aligned}
$$

The correction factor $(-0.6727)$ is less than zero, which is in accordance with the principle of reverse correction mechanism. The results show that the short-term fluctuations of the trade between the mainland and Hongkong are affected by the short-term fluctuations of the mainland to Hongkong (lnODI). When short-term fluctuations deviate from the long-term equilibrium, the non equilibrium error will be adjusted to 0.6727 of the ratio of the mainland and Hongkong's trade with the degree of correction. This shows that the mainland's investment in Hongkong on the mainland and Hongkong's trade with the formation of a positive 
feedback mechanism, is conducive to promoting economic and trade cooperation between the mainland and Hongkong.

\section{Mainland investment in Hong Kong and facing major problems exist}

Despite the rapid development of investment in the mainland to Hong Kong in recent years, but still faces some problems and constraints of its further growth. Prominent features: First, the investment industry is highly concentrated. Mainland investment in Hong Kong are mainly concentrated in business services, finance, wholesale and other retail services, the scale of investment in the emerging field of manufacturing and information transmission services, scientific research, culture and sports are still small. This suggests that mainland enterprises to take advantage of Hong Kong's service nurturing effect of advanced manufacturing, modern services, strategic emerging industries to be enhanced. Second, the regional distribution is uneven. In various regions in the Mainland, Guangdong, Shandong, Jiangsu, Zhejiang, Shanghai and other eastern coastal provinces most active foreign investment, but also to Hong Kong the largest investment in the region, while smaller in the western region the size of Hong Kong investors, accounting for more low. Third, the main structure of the investment to be optimized. State-owned enterprises, especially the relevant Mainland ministries, local government-owned enterprises are the main force in the Mainland to Hong Kong investment efforts of private enterprises to invest in Hong Kong is still insufficient. Fourth, to promote investment and service system is imperfect. Currently, fiscal, financial and other support policy for Mainland enterprises in Hong Kong direct investment to be perfect, professional services, service capacity of industry organizations needed to be further strengthened.

\section{CONCLUSION AND SUGGESTION}

The above study, we can draw the following conclusions: First, in recent years, the scale of the Mainland to Hong Kong direct investment has expanded rapidly, Hong Kong has become the largest destination for foreign investment in the Mainland, intermediary and a platform of foreign investment in the mainland has become increasingly prominent, Mainland China has become Hong Kong's largest source of foreign investment. Second, the comprehensive economic strength continued to improve the Mainland, the Mainland and Hong Kong have close geographical and humanities ties between the Mainland and Hong Kong increasingly close economic and trade exchanges, mainland enterprises to provide favorable conditions and a good investment environment in Hong Kong. Third, to maintain Hong Kong's smooth transition and smooth return of Hong Kong to promote the advantages of the service sector and manufacturing advantages of the combination of the Mainland, Hong Kong as a bridge for international operations, it is the main motivation for mainland enterprises to conduct direct investment in Hong Kong. Fourth, empirical studies have shown that direct investment in the mainland to Hong Kong is not only conducive to the promotion of economic growth in the Mainland, but also help promote the capital, movement of goods and people between the mainland and Hong Kong, so as to promote the two places to establish closer economic and trade relations. Fifth, the Mainland to invest in Hong Kong facing industry is highly concentrated, uneven regional distribution, the main structure of the investment to be optimized, investment promotion and service system of imperfect.

For the above conclusions, recommendations from the following aspects, to further promote Hong Kong's direct investment in the Mainland. First, optimize the layout of the mainland to Hong Kong industry investment. Boot the mainland in line with international market demand, with a strong advantage in processing and manufacturing enterprises to set up production bases in Hong Kong, Hong Kong as a bridge to explore the international market; encourage mainland enterprises to set up science and technology R \& D center in Hong Kong to carry out R \& D cooperation, access to international advanced technology; support Mainland trade, finance, logistics and other producer services enterprises to use Hong Kong's advantages to build a global marketing network, to create an internationally renowned brands; increasing the mainland cultural creativity, touris $m$ and other consumer services enterprises to invest in Hong Kong, led the development of new services. Second, according to the classification guidelines mainland provinces and autonomous regions to promote the expansion of Hong Kong investment. According to the level of economic development of different regions of the mainland, resource endowments scientific planning "going out" of the region, industry layout, in the eastern region to encourage enterprises to further expand investment in Hong Kong, while the central and western regions syndication large central enterprises and eastern Advantage enterprises outside help drive productivity advantages of Hong Kong as a platform to international transfer. Third is to encourage private enterprises to expand investment in Hong Kong. Select a number of strong brand, there is a market of private enterprises and key support to promote the strength of largescale private enterprises realized by product management, asset management to brand management as the core of international operations, making efforts to create a group with more Strong international competitiveness of private enterprises of trans national business, the Mainland to Hong Kong to promote the diversification of investment. Fourth, improve the service system to promote the Mainland and Hong Kong investment. The role of financial leverage to encourage cooperation in the establishment of central and local enterprises "going out" special support fund, appropriate to the mainland enterprises to invest in Hong Kong to be tilted; guide financial institutions to take advantage of favorable conditions for the Mainland and Hong Kong's financial markets are interconnected, for in Hong Kong investment management of mainland enterprises to develop syndicated loans, innovative business "within the warranty loan", the foreign assets of mortgages; major issues recommended that the Mainland and Hong Kong the relevant government departments to establish a coordination mechanism on a regular basis for Mainland enterprises to use Hong Kong platform "going out" of conduct consultation, coordinate and solve problems faced by main land enterprises 
to invest in Hong Kong; and Strengthening the Organization of chambers of commerce, associations, and enhance service capabilities Hong Kong Chinese Enterprises Association and other industry organizations, to support mainland enterprises joined the Hong Kong Chamber of Commerce, for the mainland enterprises to better operate in Hong Kong, increase outreach to provide favorable conditions.

\section{REFERENCES}

[1] Liu Yangchun. The theory and empirical research on foreign direct investment motivation of Chinese enterprises [J]. Journal of Zhongshan University (SOCIAL SCIENCE EDITION), 2008, (3).

[2] Cheng Huifang, the The location choice of China's foreign direct investmen by gravity model analysis[J]. World economy, $2004,(11)$

[3] Buckley, P., J., Clegg, A. Cross, X. Liu, H. Voss, and P., Zheng. The Determinants of Chinese Outward Foreign Direct Investment[J]. Internat ional Business Studies. 2007, (38).

[4] Li Meng, in Jinping. Study on the correlation of Host country location advantage and foreign direct investment of Chinese[J]. World economic research ,2011,(6).

[5] Kolstad, I., \& Wiig, A.. What determines Chinese out ward FDI?[R]. CHR Michelsen Institute Working Paper, 2009.

[6] Wang Jian, Zhang Hong. Research on the relationship between host country government governance and China's foreign direct investment -- Empirical Analysis Based on panel data of the host country [J]. Asia Pacific economy, 2011, (1).

[7] Benwu. China's foreign direct investment trade effect research Based on Paul data of regional differences in test [J]. Statistics and decision, 2007, (24).

[8] Liu Mingxia. The spillover effect of China's foreign investment in the reverse technology -- Analysis of the impact of the technology gap [J]. Journal of Zhongnan University of Economics and Law, 2010, (6). 